\title{
DON'T MAKE A RIVAL OUT OF THE DRAGON: RETHINKING THE EU-CHINA POLICY
}

\begin{abstract}
As expressed in the EU-China 2020 Strategic Agenda for Cooperation adopted in 2013, the European Union and the People's Republic of China are committed to a comprehensive strategic partnership. The new nature of Chinese foreign policy under the leadership of Xi Jinping has caused new problems in European-Chinese relationships. The rise of China to a position of global superpower, symbolized by the Belt and Road Initiative, has changed the conditions for EU-China relations and created a necessity for Europe to revise its approach or even to profoundly change the way it perceives relations with Beijing.

The goal of this article is to discuss EU policy towards China between 2013 and 2019 in the context of these new conditions and the changing perception of China in Europe. The rethinking process on the side of the EU was symbolized by describing China as a systemic rival in the strategic outlook presented by the European Commission in March 2019. The main research question is: how did public debate in Europe around the term systemic rival, and the change in perception of China it caused, correspond with the actual state of EU-China relationships on the level of political practice? The hypothesis, that the commotion caused by the use of the term systemic rival created a distorted impression of the current state of EU-China relations will be tested by analyzing specific cases of the operationalization of EU policy such as investment screening frameworks, European industrial policy and the major political EU-China visits and summits in 2019.
\end{abstract}

\section{Key words}

EU, China, strategic partnership, systemic rival 


\section{Introduction}

The diplomatic ties between the predecessor of the European Union (EU) - the European Community - and the People's Republic of China (PRC) were established in 1975. Since then, they have undergone several phases and their development has experienced many ups and downs. On the side of the EU, the perception of China has been evolving over the years. After recognizing it as a rising regional power before 1989, its unprecedented economic performance contributed to increasing European attention and interest in broadening cooperation, and more recently led to acknowledging China as one of the main global superpowers and to forge a bilateral strategic partnership. Diverging understanding of this partnership between the EU and China, as well as an internal European lack of coherence, has contributed to the complicated nature of the relationship.

There is an extensive literature on the topic of modern EU-China relations. Different approaches have ranged from chronological descriptions of the relationship, often dominated by economic aspects (e.g. Puślecki, 2018; Puślecki et al., 2011; Zhou, 2017), analysis through the prism of contending norms and worldviews (e.g. Ferenczy, 2018; Michalski \& Nilsson, 2018; Michalski \& Pan, 2017), applying an international context (e.g. Kerr \& Fei, 2012; Ting, 2018; Umbach, 2007), and recently - forecasting the future development of EU-China relations (e.g. Ugur, 2019). Much of the research has focused on the evolution of EU policy towards China, analyzed to a great extent through the EU's policy papers as well as strategic documents regulating bilateral relations (e.g. Cameron, 2009). Since the publication in 1995 of the document A Long Term Policy for China-Europe Relations (Commission of the European Communities, 1995), the EU "has continuously updated its strategic judgments, policy goals, work focus and implementation tools for the relationship between China and the EU, based on the changing situation" (Zhou, 2017, p. 4). Some authors have been critical of the EU's approach for being mostly "political program language" (Sandschneider, 2007, p. 136), with insufficient reference to reality; others have pointed to the fragmentation and lack of coordination of European policy towards China with each member state pursuing its own interests in relations with Beijing (e.g. Gaspers, 2018; Puślecki, 2018, p. 515; Sandschneider, 2007). It was even interpreted as competition - particularly in the economic field and in promoting national businesses - causing a negative impact for European integration (Sandschneider, 2007, p. 137).

Much of the research focused on contemplation of the strategic nature of the EU-China partnership (e.g. Ferenczy, 2018; Geeraerts, 2013; Song, 2012). 
The forging of this partnership is believed to have started in the 1990's when relations were normalized following their freezing after the Tiananmen Square events. Along with cooperation in the fields of science and environmental protection, a mechanism for the coordination of bilateral activities has been initiated, as well as regular consultations at the level of EU member states and Chinese foreign ministers concerning international and regional security issues. The EUChina leaders' summit was established in 1998. The evolution of the EU attitude towards China was symbolized by consecutive documents, such as Building a comprehensive partnership with China (Commission of the European Communities, 1998), or A maturing partnership - shared interests and challenges in EU-China relations (Commission of the European Communities, 2003), which marked the practical creation of the EU-China strategic partnership. This has deepened and broadened cooperation between both sides in many areas and created a deeper interdependence between them. In the literature the phases of development of this partnership have been variously evaluated: cooperation between the two sides was believed to have undergone a smooth development period before 2003, while several years following the 2003 document have been described as a "honeymoon" in relations (Zhou, 2017, pp. 7-8). The China-EU partnership in the first decade of the 21st century was seen by some authors as one of the most important links in world affairs (Shambaugh et al., 2008).

Publication in 2006 of another document, EU-China: Closer Partners, Growing Responsibilities (Commission of the European Communities 2006), was perceived as the next step in the direction of deepening the strategic partnership and as a symbol of the intensification of EU-China relations in the first decade of the 21st century (this could be proved by the fact, that in 2004 the EU became China's largest trade partner and China became the EU's second largest trade partner after the US). Such a step by the EU at that time was believed to have been justified due to the decentralization and liberalization of the socio-political system in China (the opposite to what is observed today). Authors even argued about the "complementarity" of the interests of the EU and China (Puślecki et al., 2011, p. 218). The relationship was complemented by various dialogue platforms for agriculture, aviation, security of consumer products, education, culture, energy production, and the natural environment. On the other hand, there was a growing conviction in the literature about existing disagreements between EU and China over the understanding of their strategic partnership. On the EU side the "conditional/conditioned engagement" policy towards China has been criticized (e.g. Fox \& Godement, 2009; Holslag, 2006). It has also been argued that "The European Commission should negotiate the prospective PCA 
(Partnership and Cooperation Agreement) more constructively, without patronizing, and instead accept China as an equal player in the current multipolar framework of global economic governance" (Leal-Arcas, 2010, p. 246). China has been perceived as much more assertive than other emerging economies such as Brazil and India - therefore the partnership with China was considered to be more difficult for the EU (Leal-Arcas, 2010, p. 245).

More recently there have been various perceptions of EU-China relations in the literature. Some authors have argued for example, that in 2017 relations entered "a stable period of development after experiencing ups and downs" (Zhou, 2017, p. vii). Others emphasized that "Europeans have been disappointed by their own inability to guide the PR China toward 'effective multilateralism' and frustrated in their support of internal political change" (Puślecki, 2016, p. 31). Much attention has also been drawn by China's growing influence in Central and Eastern Europe and its consequences for the EU (e.g. Cumpanasu, 2019; Doehler, 2019; Kowalski, 2018; Poggetti 2017; Turcsanyi, 2017; Turcsanyi, 2020). It is beyond dispute that there are major implications for the EU of China's rise to a position of a top global economy and of developments in China's foreign policy. It has been argued, that "the EU and its member states need to engage in more regular, strategic debates about China and ensure the Union speaks with one voice as far as possible" (Cameron, 2018, p. 4).

Today, 17 years after establishing the EU-China strategic partnership, discussion in Europe is centered around one main question - is China a partner, a competitor or a rival for the EU (e.g. Chen \& Hu, 2019; Ferenczy \& Ma, 2019; Puślecki, 2018; Vogt, 2012; Zhou, 2017)? The EU-China relationship has evolved significantly over the last six years. Along with this evolution, the attitude of governments and political, academic and economic elites in Europe has also been changing. The process of change in the perception of China in Europe was symbolized by describing it as a systemic rival in the strategic outlook presented by the European Commission (EC) in March 2019. The document has been perceived by public opinion as an indicator of a profound change in the EU's position towards China. Intensified by controversies around Huawei, the US-China trade conflict, the activity of Chinese state-controlled companies on the European market and lack of reciprocity in economic relations, the feeling of anxiety or even hostility towards China has mounted in Europe.

The goal of the article is to discuss the EU China-policy between 2013 and 2019 in the context of these new conditions and the changing perception of China in Europe. The main research question is: how did the public debate in Europe around the term systemic rival, and the change in the perception of China it 
caused, correspond with the actual state of the EU-China relationship on the level of political practice? The hypothesis, that the commotion caused by the use of the term systemic rival by the EU created a distorted impression of the current state of EU-China relations, will be tested by analyzing specific cases of the operationalization of EU policy towards China such as the investment screening framework, European industrial policy and major political EU-China visits and summits in 2019. In other words, the hypothesis states that contemporary EU policy towards China is characterized by complexity and multidimensionality and thus requires a broader perspective of analysis than merely through the lens of one term. It is also necessary to consider the continued commitment on both sides to develop multi-level cooperation, if only recently in the field of climate protection. Primarily the deep economic interdependence built over many years between the EU and China makes it unprofitable for both sides to downgrade or disadvantage their relationship.

\section{Part I. Strategic Partners?}

As expressed in the EU-China 2020 Strategic Agenda for Cooperation (EEAS 2013) adopted in 2013, the EU and China agreed to continue and develop their comprehensive strategic partnership in the next decade based on the principles of equality, respect and trust and looking for synergies between their respective development strategies, aiming for win-win results.

The EU-China partnership is cemented by their extensive economic ties. Bilateral trade is constantly rising, although with a permanently unfavorable balance on the side of the EU (see Figure 1). There is also an intensive investment flow between both sides with Chinese foreign direct investments (FDI) in the EU peaking in 2016 with a value of over 37 billion euros and the annual value of EU's FDI in China oscillating around the level of 8 billion euros (see Figure 2).

The direction of social, political and economic models of development in modern China, ruled by President Xi Jinping, especially after consolidation of power in the hands of the Communist Party of China and of Xi himself in 2017, has become clearly divergent from Western-style democracy and a free market economy. The new nature of Chinese foreign policy has also caused new problems in European-Chinese relationships. The rise of China to a position of a global superpower, symbolized by the Belt and Road Initiative, creates a necessity for Europe to revise its approach or even to profoundly change the way it perceives EU-China relations. This process has already been visible within discussions about how to improve EU competitiveness and about protecting the internal 
Figure 1. EU trade in goods with China flows and balance: 2013-2018 (EUR billion)

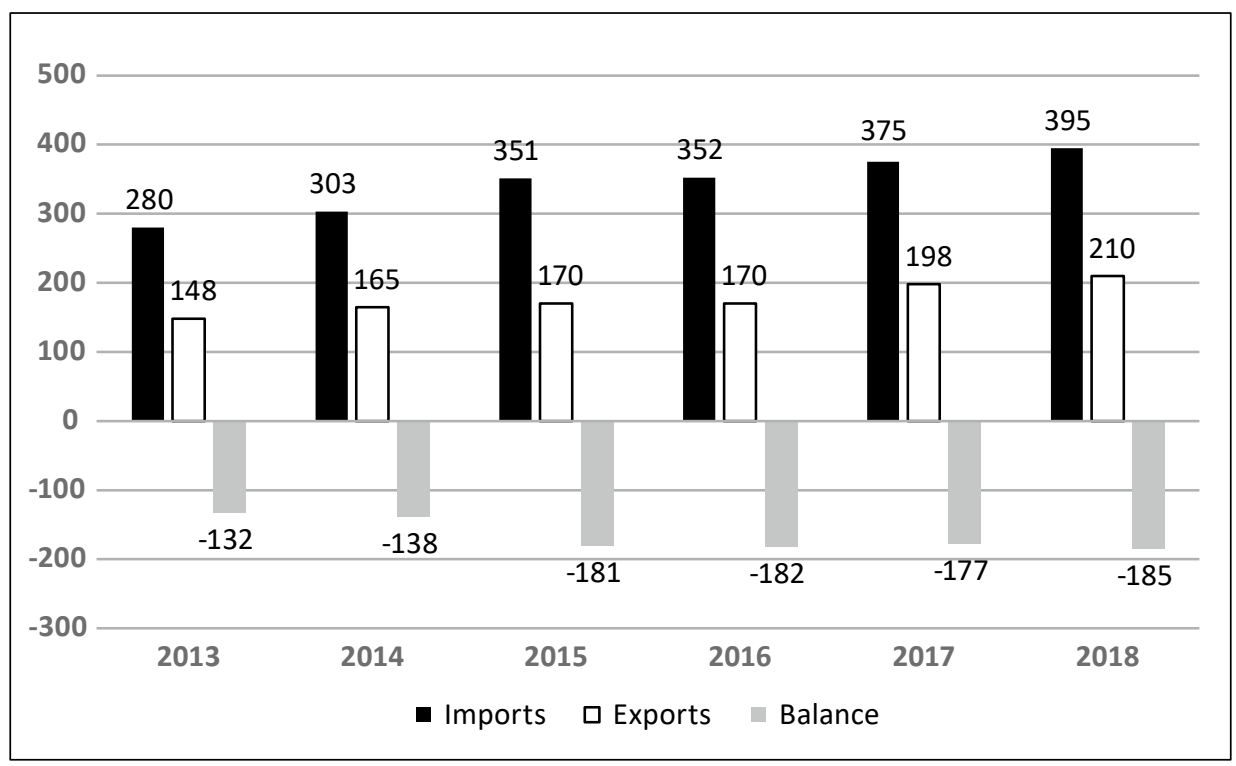

Source: European Commission, Directorate-General for Trade 2019

Figure 2. Foreign Direct Investment flows between EU and China: 2013-2018 (EUR billion)

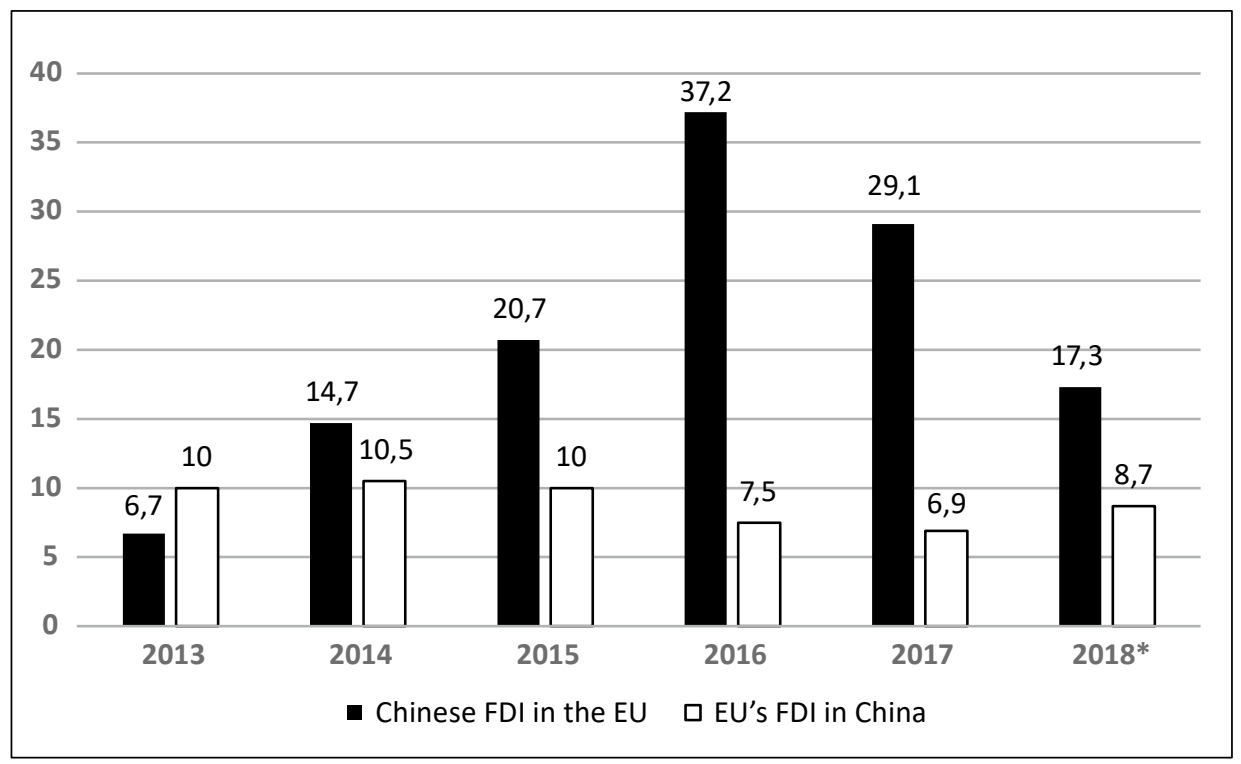

Source: Merics \& Rhodium Group 2018 and 2019, Eurostat 2019 
market from questionable foreign activity. It has also made divisions between member states visible, concerning an appropriate way for the EU to position itself in a globally competitive market dominated by China and the USA.

During the last five years it has become clear that Chinese $5^{\text {th }}$ generation leaders (primarily President Xi Jinping and Prime Minister Li Keqiang), basing on Deng Xiaoping's vision of "reforms and opening", realize their own "Going Global" strategy with slogans on the "Chinese dream" and the "great renaissance of the Chinese nation". Its purpose is to make China the greatest power in the world by 2050; a process understood as regaining the position China deserves and had lost. The unprecedented economic success of the Chinese model in recent years has given the nation and its leaders a new kind of self-assurance.

As Robert Kagan put it, "In the projection of the Communist Party of China, the West loses its monopoly on the realization of the process of globalization" (Kagan, 2009). The success story of the Chinese model confirms the direction of building welfare and stability without necessarily changing the political regime towards a Western-style democracy. China pursues its own socio-political-economic model - often discordant to that of the West - according to the "Thought on Socialism with Chinese Characteristics for a New Era" (Xiang, 2017), as written into the Chinese constitution during the 19th National Congress of the Communist Party of China (CPC) in October 2017. One of the model's characteristics is the strong position of the party which treats the state as a tool of executing its authority. On the domestic arena there is a concentration of power in the hands of the CPC leadership and President Xi Jinping (particularly after the party's decision in March 2018 to end the two-term limit on the presidency), essential to his conservative turn (see Bogusz \& Jakóbowski, 2019). Furthermore, the government has tightened its control over social processes and attempts to control them using modern technologies, which often results in the limiting of pluralism, freedom of views, human rights and political competition; state interventions into economic processes are another characteristic, leading to overcapacity and market distortions. Active state industrial and innovation policies aim at attaining technological hegemony; while the competition is constrained by market isolation and to the advantage of native companies and producers (BDI, 2019). The model is completed by an assertive, active and self-aware foreign policy,

${ }^{1} 2018$ marked the $40^{\text {th }}$ anniversary of the Chinese "opening to the world". In late 1978 the Communist Party of China introduced economic reforms, designed by Deng Xiaoping, which have initiated a process of social and political change and led to the opening of the Chinese market for foreign investors. 
conducted regionally as well as globally. Its core element - the Belt and Road Initiative (BRI) - is a tool of developing infrastructure and connectivity throughout Eurasia and of interconnecting China with numerous countries along the New Silk Road (e.g. Li \& Taube, 2018; Semenova, 2019). The significance of the BRI can be proved by the fact that it has already been recognized in Europe as a possible alternative to the WTO (Ossenkopp, 2018).

In the pursuit of its new global strategy, China does not seem to consider its strategic partnership with the EU as a constraint. As Xi Jinping announced the BRI in 2013, negotiations regarding the EU-China 2020 Strategic Agenda for Cooperation were still in progress. The projects have not been linked as China did not accept the primacy of EU rules in the process of developing economic relations with individual member states. It was a clear sign of Beijing's dual approach and differentiating between two levels of relations: EU institutional and bilateral. This approach provided severe complications and problems in EU-China relations that have only partially been limited by introducing the EU-China Connectivity Platform in 2015.

At the same time, Chinese political scientists argue that the development towards democracy and a market economy can still occur in China (Bubrowski, 2019). They remind us that the country is just at the beginning of a longer process, and that in China there are still 100 million people living in extreme poverty according to World Bank criteria. China has to solve internal problems first, as the argument goes, and then step forward and take more responsibility on the global stage. One has to bear in mind that a country with such an enormous population has to be analyzed from an entirely different perspective than European states. Chinese problems may become extremely serious or quite insignificant - depending if one multiplies or divides them by roughly 1.4 billion citizens. Europe should better understand the characteristics of the Chinese political, social and economic system as different from European standards. Since the fall of the Soviet Union, Europe has not had to deal with a big, centrally-planned and state-controlled economy, and this results in misunderstandings. This is a big analytical and research challenge for Europe.

Beijing's intention today is to conduct a change of the international order so that it better reflects the Chinese position and preferences (e. g. Lee et al., 2020). According to Maull, it makes China a revisionist power, but not a revolutionary one (Maull, 2018, pp. 290-291). It is hardly disputable that the international position of China is constantly rising (e.g. Weiss, 2019). As Betz argues, in economic policy "China has made a transition from a hard-frozen opponent of globalization, and the international organizations supporting it, to a role as 
a conscientious member of those organizations and an advocate of free capitaland goods exchange, and is today more economically open than most emerging economies" (Betz, 2012, p. 226). In the above context, the question remains open, should the EU-China relationship be perceived today as "global rivalry" (Sandschneider, 2007), or is the precondition for the gradual development of EU-China relations that both sides see each other as strategic partners rather than strategic competitors (Zhou, 2017a).

\section{Part II. It's in the name: systemic rival and what it means}

The process of change in the perception of China in Europe was symbolized by describing China as a systemic rival in the strategic outlook presented by the European Commission in March 2019. The document has been perceived by public opinion as an indicator of a profound change in the EU's position towards China.

The purpose of the EC strategic outlook was "delivering a further EU policy shift towards a more realistic, assertive, and multi-faceted approach" (European Commission, 2019i). The document was also a basis for preparing a new longterm industrial policy for the EU until 2030. In the document, the EC pointed out 10 specific actions for discussion and endorsement by the European Council, such as:

- strengthening cooperation with China to meet common responsibilities across all three pillars of the United Nations: Human Rights, Peace and Security, Development;

- calling on China to peak its emissions before 2030, in line with the goals of the Paris Agreement;

- deepening engagement with China on peace and security, building on the positive cooperation on the Joint Comprehensive Plan of Action for Iran;

- applying more robustly the existing bilateral agreements and financial instruments, and working with China to follow the same principles;

- calling on China to deliver existing joint EU-China commitments in order to achieve a more balanced and reciprocal economic relationship;

- adopting the International Procurement Instrument before the end of 2019 to promote reciprocity and open up procurement opportunities in China;

- ensuring that not only price but also high levels of labor and environmental standards are taken into account when it comes to participation of foreign bidders and goods in the EU procurement market; 
- identifying how to fill existing gaps in EU law to fully address the distortive effects of foreign state ownership and state financing in the internal market;

- evolving a common EU approach to the security of 5G networks to safeguard against potentially serious security implications for critical digital infrastructure;

- ensuring the swift, full and effective implementation of the regulation on the screening of foreign direct investment by member states, to detect and raise awareness of security risks posed by foreign investment in critical assets, technologies and infrastructure.

The most intensively discussed sentence of the document was the one describing China as a systemic rival. In the public debate those two words became a symbol of change in the perception of China in Europe from partner to rival, and the shifting of the EU's priorities towards the East (e.g. von der Burchard, 2019; Escobar, 2019; Wilhelm, 2019). As polls indicated, in September 2019 the majority of EU citizens believed China's aggressive competitive practices are a threat to their economic interests (Taylor, 2019).

The strategic outlook presented by the EC is definitely worth attention for more reasons than just the introduction of new terminology. An analysis of the document in the broader context of EU-China relations makes it harder to consider it as an indicator of a fundamental shift in the EU position towards China. It is worth citing the whole sentence containing the term systemic rival. It shows an attempt by the EC to paint a more nuanced, realistic and multifaceted picture of China:

China is, simultaneously, in different policy areas, a cooperation partner with whom the EU has closely aligned objectives, a negotiating partner with whom the EU needs to find a balance of interests, an economic competitor in the pursuit of technological leadership, and a systemic rival promoting alternative models of governance (European Commission, 2019c).

It is also worth noting, that the EC strategic outlook was preceded by a document published by the Federation of German Industry (BDI) in January 2019, entitled "Partners and systemic competitors" (BDI, 2019). Although the BDI is not an official government body, it plays an important role in German public debate and has a significant influence on the process of shaping Berlin's policy. The main declared reason behind the document was an ascertainment of the fact that there is a systemic competition between two models: the German/European model of a liberal, open and social market economy and the Chinese model 
of an economy controlled by state (BDI, 2019). The main question addressed by the BDI was how should Germany and the EU deal with a Chinese statecontrolled economy? The document brought in a new voice, proposing a more assertive and tougher stance towards China. The BDI formulated 54 recommendations for Germany and the EU on how to make the economy more resilient and effective, and not to fall behind in global competition. It was stressed by the BDI that foreign investment (also from China) is generally welcome from the perspective of Germany and the EU. Freedom of private ownership and freedom of agreements were recognized as pillars of a liberal market economy that need to be maintained; simultaneously it was considered essential to introduce new instruments to the market and competition protection on an EU level in order to ensure equal chances and reciprocity in economic relations. The BDI warned, however, that such protection measures, if excessively expanded, could easily lead to protectionism.

As the Federation of German Industry argued, cooperation despite competition is necessary between the EU and China. The EU should not isolate China - despite systemic differences - both sides should cooperate in a pragmatic manner for their own interests.

\section{Part III. What is actually going on? The practical level: political reality and facts}

It is worth examining the activity of the EU towards China on the practical level of political reality and facts, including political decisions, legislation, discourse in documents and elite debates. The thesis about a profound change in EU policy towards China, symbolized by the term systemic rival, can be verified and softened in this context.

\section{Investment screening framework}

The positive reception of Chinese investors' activity in the EU expired after they shifted their focus to sectors included in the "Made in China 2025" strategy as essential for future development, such as robotics, mechanical engineering, IT, telecommunication, weapons production, high tech and energy. A discussion in Europe has been initiated about the necessity to protect EU economies from the acquisitions of important companies in those sensitive sectors due to concerns about national interest or even security. The Chinese economic offensive was also perceived as a tool of know-how drainage, lowering EU competitiveness in the global race to Industry 4.0. The structure of Chinese investment is 
especially viewed with criticism in Europe, for example, 20-25\% of Chinese investors active in Germany are variously dependent on or controlled by the government in Beijing ${ }^{2}$.

The turning point that triggered a critical reaction were the acquisitions of two German companies KUKA (robotics) and KraussMaffei (machinery) in 2016 by the Chinese firms Midea and ChemChina. After numerous calls on the German administration in public debate to introduce tools of protection for sensitive sectors from foreign acquisitions, the government in Berlin has sharpened the foreign trade and investment law by lowering the threshold for governmental investment control to $10 \%$ of shares (Außenwirtschaftsverordnung vom 2 . August 2013). Although it was not to be expected from Germany, an advocate of free trade and open markets, to introduce severe market protection mechanisms in practice, the government's reaction symbolized an increase in German awareness and assertiveness towards China which was transferred to the European level as a next step.

As an effect of a "trilogue" between EU institutions initiated by Germany, France and Italy in 2017, an agreement on an EU foreign investment screening framework was reached in November 2018 and confirmed by the European Parliament in February 2019. The cooperation mechanism was created for member states and the Commission to be able to exchange information and raise specific concerns. The EC was allowed to issue opinions in cases concerning several member states, or when an investment could affect a project or program of interest to the EU as a whole (such as Horizon 2020 or Galileo). It was emphasized, however, that member states were to have the last word whether a specific operation should be allowed or not in their territory and that new regulations would not affect member states' ability to maintain their existing review mechanisms, to adopt new ones or to remain without such national mechanisms (European Commission, 2018). Currently 15 of 28 member states have national screening mechanisms for foreign investment (European Commission, 2019d). The purpose of the screening framework was to ensure protection of member states' interests and at the same time to maintain openness on the internal market to foreign investment, fueling economic growth, innovation and employment.

2 Various models of dependence include entirely state-controlled companies, SASAC companies (SASAC: State-owned Assets Supervision and Administration Commission), companies with mixed private-public ownership structure, companies with internal units and companies with a lack of transparency in their finance structures and informal ties to the government. See Jungbluth, 2018. 


\section{European industrial policy}

A similar mechanism for transferring German internal ideas for policy on China to a European level was visible in the case of industrial policy. Just two weeks after the German National Industry Strategy 2030 had been presented by the German economy minister Peter Altmaier in February 2019, the discussion was "Europeanized" with the Franco-German Manifesto for a European industrial policy fit for the $21^{\text {st }}$ century (BMWi, 2019). The most discussed point of the document was the proposed change in EU competition rules in order to enable mergers such as between Siemens and Alstom (which had been blocked by the EC to discontent in Berlin and Paris). Justified by the need to create European champions - companies able to compete on a global level with Chinese and American giants - the French-German argument did not win wide support among other member states.

Criticism came from experts too - in an open letter signed by 37 leading European economists it was argued that the Siemens-Alstom merger would lead to lowering of competition on the European market, an increase in prices by the new consortium, and the lowering of expenditure on research and new technologies. Their argument was later expanded by Haucap (2019), who argued that internal market competition rules were too loose rather than too tight; he also pointed to the fact that a merger between two European companies is not the right remedy for the main problem of limited access to the Chinese market for companies from the EU.

Controversies around the Siemens-Alstom merger concerned the degree to which a state or the EC should intervene in a free market economy and support given companies or mergers. Accusations of violating the free market orientation on the one side were countered by emphasizing the need for the EU to become a global competitor on the other. At the same time a more important general debate has been initiated about long term European industrial strategy, strengthening the social market economy model, and increasing investment in innovations. At the same time protection measures were discussed, referring - indirectly - to China. So far, no consensus has been achieved among several groups of member states differing in their attitude. Northern European countries (e.g. Netherlands, Sweden) and free market advocates (e.g. Poland) shared the general French-German diagnosis about the necessity of strengthening European industrial policy and its global competitiveness, but did not support the methods proposed, especially towards loosening the competition rules. The debate around European industrial strategy (and around the screening mechanism) was, nevertheless, an important stage in the process of rethinking EU China-policy. 


\section{EU-China visits and summits in 2019}

\section{Xi Jinping's visit to Europe (March $21^{\text {st }}-27^{\text {th }}$ )}

The visit of Xi Jinping to three European countries (Italy, Monaco and France) in March 2019 was another opportunity to observe the practical dimension of EU China-policy and its complicated character. Taking place 10 days after the EC described China as a systemic rival, the meetings in Rome and in Paris had a distinctly different political resonance. Italy signed a Memorandum of Understanding, as the first G7 country to join the BRI, which drew criticism from EU institutions and other member states who accused Italy of eroding European unity and China of playing differences within the EU against it. Xi's visit to France on the other hand was a demonstration of a common, coordinated European approach. President Emmanuel Macron, who called the "time of European naïveté" (Peel et al., 2019) towards China to end, broadened the format by inviting German chancellor Angela Merkel and EC President Jean-Claude Juncker to take part in the meeting. It showed that Germany and France were pursuing an assertive, self-assured attitude towards China. At the same time, China in Paris played the role of a partner respecting the collective character of the EU and promoting multilateralism in global issues.

\section{$21^{\text {st }}$ EU-China Summit (April $9^{\text {th }}$ )}

It is important to take note of an increased Chinese charm offensive in the European media in the run-up to the EU-China Summit in April 2019. In an interview for the German newspaper Handelsblatt before the summit, the Chinese prime minister, Li Keqiang, had declined accusations that dividing the EU was a deliberate action. He described China and Europe as partners in win-win cooperation and in building peace and stability around the world. Li also declared China's support for a strong, integrated EU (Keqiang, 2019). China's EU ambassador, Zhang Ming, opposed calling China a systemic rival, as it is "not adequate even for Cold War conditions, when there were even more significant differences between two blocs" (Vinocur \& Cerulus, 2019).

The summit itself was declared a success by both sides, although there were signals of tough negotiations and even some frustration on the Chinese side. The signature on the joint statement was an important step for the EU in toughening its stance - the Chinese side had to fulfill some conditions that were stated by the EU (Smith \& Taussig, 2019). In many points solid statements were agreed with time frames instead of general declarations. For instance, both sides declared the will to sign an agreement on Geographical Indicators by the end of 
2019 as well as to finalize negotiations on the EU-China Comprehensive Agreement on Investment. Until the next EU-China summit, both sides should find mutually agreeable solutions to a number of key barriers in bilateral trade.

During the summit, the EU and China reaffirmed the strength of their comprehensive strategic partnership. Both sides declared cooperation towards multilateralism, international law and the fundamental norms of international relations, with the key role for the United Nations. The EU and China expressed support for international trade under WTO rules, their commitment to work within the G20 and to implement the Paris Agreement on climate change. From the European perspective, another important declaration concerned cooperation on WTO reform and on strengthening international rules on industrial subsidies (European Commission, 2019).

\section{6+1 Summit in Dubrovnik (April 11 $1^{\text {th }}$ )}

China's activity in Central and Eastern Europe (CEE) is another factor contributing to anxiety on the side of the EU and fueling criticism in some member states. Although this issue goes beyond the scope of this article, it is worth mentioning the $16+1$ initiative $^{3}$, which is often perceived as a tool of China's divide and rule strategy. As the argument follows, China makes countries taking part in 16+1 dependent economically and by doing so, discourages them from supporting tougher EU policy on problematic issues such as human rights, China's activity in South China Sea, or the situation in Hong Kong. Although Chinese activity in CEE may cause political tensions, the economic indicators do not support this thesis. Chinese investment in the EU is still focused mainly in Western Europe ${ }^{4}$, while CEE countries still receive most of their foreign investment from the USA and other EU member states.

By including Greece and broadening the format to 17+1 at the 2019 Summit in Dubrovnik, China showed commitment to the initiative and a readiness to develop it in the future, despite its rather limited success thus far. On the other hand a certain softening of the Chinese position could be noticed in recent years, as EU representatives were included as observers during $16 / 17+1$ summits and the texts of the official statements exhibited efforts

3 Officially: China-CEEC/China-Central and Eastern European Countries Cooperation Initiative.

4 According to Merics Institute, 24\% of total Chinese FDI (foreign direct investment) in the EU in 2018 was received by the UK, $12 \%$ by Germany and only $2 \%$ by the Central Europe region. See: Hanemann et al., 2019. 
to harmonize the Chinese-led projects with European standards, for instance with the EU-China Connectivity Platform. What is more, the prospect was opened for Germany to join the initiative.

\section{Part IV. Conclusions and the way forward}

The new character of Chinese foreign policy has redefined the EU-China relationship. Deep economic ties form a strong foundation for this relation. However, recent developments in China's internal and foreign policies are generating disappointment and anxiety on the side of the EU, and this causes many of the current problems in the relationship. It is a challenge requiring adjustment of the EU China-policy, or even a profound change in the way of thinking about China in Europe.

The re-thinking process has already begun and has been visible within discussions about the screening framework and the new European industry strategy; it also made divisions between member states apparent, concerning an appropriate way for the EU to position itself in bilateral relations with China as well as in global competition dominated by China and USA. This process will continue despite the confusion caused by the term systemic rival as used by the EC to describe China in the strategic outlook from March 2019. The analysis conducted in the article proved that the alleged dramatic change in the EU's China-policy symbolized by the term systemic rival did not correspond with the actual state of the EU-China relationship on the level of political practice. Putting the term systemic rival into a broader context of EU-China relations enabled the hypothesis - to perceive the EC strategic outlook not as a symbol of a fundamental shift in EU China-policy, but as an element of a more general, multi-faceted and long-term process, was verified. The EU and its member states attempt to react to the new reality created by China's rise to a position of a global superpower and its competition with the USA. To retain the role of an equally important actor on the international stage, the EU needs to "recalibrate the compass" in its China-policy, rather than to entirely reverse the direction of its development. China is at the same time a challenging and an indispensable partner for Europe, imposing hard conditions that require harmonized and possibly uniform reaction from EU member states. Economic interdependence dictates the necessity of maintaining mutually satisfactory relations despite political differences. In other words, what is essential for the EU-China relationship is continuous, pragmatic cooperation despite the existing systemic competition. 
It will be interesting to observe how the EU China-policy evolves with the new European Commission and its President Ursula von der Leyen. The COVID-19 pandemic has added a new context to EU-China relations, making them even more complicated and challenging for Europe. China's deliberate attempts to shape a positive narrative of its effectiveness in dealing with the pandemic at home and to present itself as a reliable partner intending to foster multilateral response to corona-crisis are countered by hard and critical reaction from the US. This requires a cautious reaction and a clever balancing act from the EU, which should protect European unity, continue dialogue with the PRC, but at the same time account for such Chinese actions as lack of transparency in dealing with the pandemic, continuous unfair trade policies or violating the rights of Hong Kong. An important political opportunity will certainly be the first, historical summit between China and leaders of all the EU member states, to be organized by Germany during its presidency of the European Council in September 2020.

\section{REFERENCES}

Außenwirtschaftsverordnung vom 2. August 2013 (BGBl. I S. 2865), die zuletzt durch Artikel 1 der Verordnung vom 27. Februar 2019 (BAnz AT 06.03.2019 V1) geändert worden ist. Retrieved from http://www.gesetze-im-internet.de/awv_2013/AWV.pdf BDI (Bundesverband der Deutschen Industrie). (2019, Jan). Partner und systemischer Wettbewerber - Wie gehen wir mit Chinas staatlich gelenkter Volkswirtschaft um? Grundsatzpapier China. Retrieved from https://g8fip1kplyr33r3krz5b97d1-wpengine. netdna-ssl.com/wp-content/uploads/2019/01/BDI-Grundsatzpapier_China.pdf

Betz, J. (2012). Neue regionale Führungsmächte und Dritte Welt. In D. Flemes, D. Nabers, \& D. Nolte (Eds.), Macht, Führung und Regionale Ordnung. Theorien und Froschungsperspektiven (pp. 209-235), Weltregionen im Wandel, 12. Baden-Baden: Nomos.

BMWi (Bundesministerium für Wirtschaft und Energie). (2019). A Franco-German Manifesto for a European industrial policy fit for the 21st Century, Retrieved from https://www.bmwi.de/Redaktion/DE/Downloads/F/franco-german-manifesto-fora-european-industrial-policy.pdf?__blob=publicationFile\&v=2

Bogusz, M., \& Jakóbowski, J. (2019). Komunistyczna Partia Chin i jej państwo. Konserwatywny zwrot Xi Jinpinga. Warsaw: Centre for Eastern Studies.

Bubrowski, H. (2019, 3 Jun). China ist noch unerfahren auf der internationalen Bühne. Frankfurter Allgemeine Zeitung. Retrieved from https://www.faz.net/aktuell/politik/ inland/china-international-us-haltung-zu-huawei-ist-irrational-16218901.html 
Burchard, H. von der. (2019, 12 Mar). EU slams China as 'systemic rival' as trade tension rises. Politico. Retrieved from https://www.politico.eu/article/eu-slams-China-assystemic-rival-as-trade-tension-rises/

Cameron, F. (2009). The Development of EU-China Relations. In G. Wiessala, J. Wilson, \& P. Taneja (Eds.), The European Union and China. Interests and Dilemmas (pp. 47-64). European Studies, 27. Brill. DOI: https://doi.org/10.1163/9789042027428

Cameron, F. (2018). China's More Assertive Foreign Policy - Implications for the EU. EU-China Observer, 1(18), 4-8.

Chen, D., \& Hu, J. (2019, 8 Apr). Are the European Union and China Systemic Rivals? The Diplomat. Retrieved from https://thediplomat.com/2019/04/are-the-europeanunion-and-China-systemic-rivals/

Commission of the European Communities. (1995, 5 Jul). Communication from the Commission. A Long Term Policy For China-Europe Relations. COM(95) 279. Brussels. Retrieved from https://op.europa.eu/en/publication-detail/-/publication/0bcbclc72c78-4bba-a027-f67035eeac4f/language-en

Commission of the European Communities. (1998, 25 Mar). Communication from the Commission. Building a Comprehensive Partnership with China. COM(1998) 181. Brussels. Retrieved from https://eur-lex.europa.eu/LexUriServ/LexUriServ.do?uri= COM:1998:0181:FIN:EN:PDF

Commission of the European Communities. (2003, 10 Sep). Commission Policy Paper For Transmission to the Council and the European Parliament. A maturing partnership - shared interests and challenges in EU-China relations. COM(2003) 533. Brussels. Retrieved from https://eur-lex.europa.eu/LexUriServ/LexUriServ.do?uri= COM:2003:0533:FIN:EN:PDF

Commission of the European Communities. (2006, 24 Oct). Communication from the Commission to the Council and the European Parliament - EU-China: Closer partners, growing responsibilities. COM(2006) 632. Brussels. Retrieved from https:// eur-lex.europa.eu/legal-content/EN/TXT/?uri=celex:52006DC0631

Cumpanasu, B. L. (2019). China's linkages and leverages in Central and Eastern Europe - a new challenge for EU. CES Working Papers, XI(3).

Doehler, A. (2019, Sep 25). How China Challenges the EU in the Western Balkans. The Diplomat. Retrieved from https://thediplomat.com/2019/09/how-China-challenges-the-eu-in-the-western-balkans/

EEAS. (2013, 23 Nov). EU-China 2020 Strategic Agenda for Cooperation. Retrieved from http://eeas.europa.eu/archives/docs/China/docs/eu-China_2020_strategic_agenda_ en.pdf

Escobar, P. (2019, 27 Mar). The EU bows to 'systemic rival' China. Asia Times. Retrieved from https:/www.asiatimes.com/2019/03/article/the-eu-bows-to-systemic-rival-China/

European Commission. (2018, 20 Nov). Commission welcomes agreement on foreign investment screening. Press release. Brussels. Retrieved from https:/ec.europa.eu/ commission/presscorner/detail/en/IP_18_6467 
European Commission. (2019a, 9 Apr). EU-China Summit Joint statement. Brussels. Retrieved from https://www.consilium.europa.eu/pl/press/press-releases/2019/04/09/ joint-statement-of-the-21st-eu-China-summit/

European Commission. (2019b, 3 Jun). European Union, Trade in goods with China. Directorate-General for Trade. Retrieved from https://webgate.ec.europa.eu/isdb_ results/factsheets/country/details_China_en.pdf

European Commission. (2019c, 12 Mar). Joint Communication To The European Parliament, The European Council And The Council. EU-China - A strategic outlook. Strasbourg.

European Commission. (2019d, 22 Jun). List of screening mechanisms notified by Member States. Retrieved from https://trade.ec.europa.eu/doclib/docs/2019/june/tradoc_ 157946.pdf

Eurostat. (2019, 17 Jul). EU Foreign Direct Investment flows in 2018. Retrieved from https://ec.europa.eu/eurostat/en/web/products-eurostat-news/-/DDN-20190717-1

Ferenczy, Z. A. (2018). The EU-China Strategic Partnership: Normative Divergence and Global Governance. EU-China Observer, 1(18), 13-17.

Ferenczy, Z. A., \& Ma, J. (2019, 4 Dec). The EU and China: Partners or Rivals in an Emerging World Order? Pacific Forum, PacNet, 65. Retrieved from https://www. academia.edu/41435356/THE_EU_AND_CHINA_PARTNERS_OR_RIVALS_IN_ AN_EMERGING_WORLD_ORDER

Fox, J., \& Godement, F. (2009). A Power Audit of EU-China Relations. Policy Report. London: European Council on Foreign Relations.

Gaspers, J. (2018). Schluss mit der Scheinheiligkeit. Chinas Politik spaltet Europa. Die EU muss für eine gemeinsame Linie sorgen. Internationale Politik, 2/2018, 24-29.

Geeraerts, G. (2013). EU-China Relations. In T. Christiansen, E. Kirchner, \& P. Murray (Eds.), The Palgrave Handbook of EU-Asia Relations (pp. 492-508). Basingstoke: Palgrave Macmillan.

Hanemann, T., Huotari, M., \& Kratz, A. (2019, Mar 6). Chinese FDI in Europe: 2018 trends and impact of new screening policies. Rhodium Group and MERICS. Retrieved from https://www.merics.org/en/papers-on-china/chinese-fdi-in-europe-2018

Haucap, J. (2019, 18 Feb). Europa braucht eine Antwort auf Chinas Industriepolitik. Frankfurter Allgemeine Zeitung. Retrieved from https://www.faz.net/aktuell/ wirtschaft/haucap-gastbeitrag-europa-braucht-antwort-auf-chinas-industriepolitik-16324331.html

Holslag, J. (2006). The European Union and China: The Great Disillusion. European Foreign Affairs Review, 11, 555-580.

Jungbluth, C. (2018). Kauft China systematisch Schlüsseltechnologien auf? Chinesische Firmenbeteiligungen in Deutschland im Kontext von "Made in China 2025”. Gütersloh: GED Studie, Bertelsmann Stiftung.

Kagan, R. (2009). Powrót historii i koniec marzeń. Poznań: Rebis. Cited in Walkowski, M. (2017). Chiński model rozwoju społeczno-gospodarczego i jego potencjalna adaptacja w Europie. Przegląd Strategiczny, 10, 341-342. 
Keqiang, L. (2019, 8 Apr). Embracing Openness and Cooperation for Mutual Benefit. Gastkommentar. Handelsblatt. Retrieved from https:handelsblatt.com/meinung/ gastbeitraege/gastkommentar-embracing-openness-and-cooperation-for-mutualbenefit/24193230.html?ticket=ST-12249979-R5WgeqGccrxVhfiT0skQ-ap2

Kerr, D., \& Fei, L. (Eds.). (2012). The International Politics of EU-China Relations. British Academy Scholarship Online. DOI:10.5871/bacad/9780197264089.001.0001

Kowalski, B. (2018, 13 Jul). What's Next for the China-CEE 16+1 Platform? The Diplomat. Retrieved from https://thediplomat.com/2018/07/whats-next-for-the-Chinacee-161-platform/

Leal-Arcas, R. (2010). European Union-China Trade Relations. Trade, Law and Development, II(224), 225-251.

Lee, P. K., Heritage, A., \& Mao, Z. (2020). Contesting liberal internationalism: China's renegotiation of world order. Cambridge Review of International Affairs, 33(1), 52-60.

Li, Y., \& Taube, M. (2018). The implications of the 'Belt and Road Initiative' on globalization and inclusive growth for the Eurasian continent. Journal of Chinese Economic and Business Studies, 16(3), 233-240.

Maull, H. W. (2018). Conclusions: The Rise and Decline of the Liberal International Order. In H. W. Maull (Ed.), The Rise and Decline of the Post-Cold War International Order (pp. 272-312). Oxford: Oxford University Press.

Merics \& Rhodium Group. (2018, May). EU-China FDI: Working Towards Reciprocity in Investment Relations. Merics Papers on China 3. Retrieved from https://www.merics. org/sites/default/files/2018-08/180723_MERICS-COFDI-Update_final.pdf

Merics \& Rhodium Group. (2019, Mar), Chinese FDI in Europe: 2018 Trends and Impact on New Screening Policies. Merics Papers on China. Retrieved from https://www.merics.org/sites/default/files/2019-03/190311_MERICS-Rhodium\%20Group_COFDIUpdate_2019.pdf

Michalski, A., \& Nilsson, N. (2018). Resistant to Change? The EU as a Normative Power and Its Troubled Relations with Russia and China. Foreign Policy Analysis, 15(3), 432-449.

Michalski, A., \& Pan, Z. (2017). Unlikely Partners? China, the European Union and the Forging of a Strategic Partnership. Singapore: Palgrave Macmillan. DOI: 10.1007/ 978-981-10-3141-0

Ossenkopp, S. (2018, 19 Nov). Is Germany ready? China's New Silk Road. Diplomatisches Magazin. Retrieved from https://www.diplomatisches-magazin.de/en/article/ chinas-neue-seidenstrasse-ist-deutschland-bereit/

Peel, M., Mallet, V., \& Johnson, M. (2019, 22 Mar). Macron hails 'end of Europe naïveté' towards China. Financial Times. Retrieved from https://www.ft.com/content/ ec9671ae-4cbb-11e9-bbc9-6917dce3dc62

Poggetti, L. (2017, 24 Nov). China's Charm Offensive in Eastern Europe Challenges EU Cohesion. The Diplomat. Retrieved from https://thediplomat.com/2017/11/Chinascharm-offensive-in-eastern-europe-challenges-eu-cohesion/ 
Puślecki, Z. W. (2016). The new challenges for economic relations between European Union and China. Studia Ekonomiczne, Zeszyty Naukowe Uniwersytetu Ekonomicznego, 266, 18-35.

Puślecki, Z. W. (2018). Unia Europejska - Chiny. Nowe zjawiska w stosunkach handlowo-ekonomicznych. Poznań: Poznańskie.

Puślecki, Z. W., Walkowski, M., \& Szymczyński, T. R. (2011). Unia Europejska wobec wzrostu konkurencyjności Brazylii, Rosji, Indii i Chin (BRIC). Warszawa: Elipsa.

Sandschneider, E. (2007). Globale Rivalen. Chinas unheimlicher Aufstieg und die Ohnmacht des Westens. München: Carl Hanser Verlag.

Semenova, N. (2019). Security issues in transport projects in Central Asia. The Copernicus Journal of Political Studies, 2, 117-129.

Shambaugh, D., Sandschneider, E., \& Zhou, H. (2008). Introduction. In D. Shambaugh, E. Sandschneider, \& H. Zhou (Eds.), China-Europe relations: Perceptions, policies and prospects. London: Routledge.

Song, X. (2012). Challenges and Opportunities in EU-China Relations. In R. Vogt (Ed.), Europe and China: Strategic Partners or Rivals? (pp. 19-36). Hong Kong: Hong Kong University Press.

Smith, J., \& Taussig, T. (2019). The Old World and the Middle Kingdom. Europe Wakes Up to China's Rise. Foreign Affairs, 98(5).

Taylor, C. (2019, 20 Sep). Most Europeans see China's 'aggressive policies' as a threat to their economic interest, survey shows. CNBC. Retrieved from https://www.cnbc. com/2019/09/20/most-europeans-see-Chinas-aggressive-trade-practices-as-a-threat. html

Ting, W. (2018). EU-China Relations After Brexit. In D. Huang, \& M. Reilly (Eds.), The Implications of Brexit for East Asia (pp. 91-112). Singapore: Palgrave Macmillan. Turcsanyi, R. Q. (2017, 29 Nov). Growing Tensions Between China and the EU Over 16+1 Platform. The Diplomat. Retrieved from https://thediplomat.com/2017/11/ growing-tensions-between-China-and-the-eu-over-161-platform/

Turcsanyi, R. Q. (2020). China and the Frustrated Region: Central and Eastern Europe's Repeating Troubles with Great Powers. China Report, 56(1), 60-77. DOI: https://doi. org/10.1177/0009445519895626

Ugur, O. (2019). EU-China Relations Current and Future. In F. Koksoy (Ed.), Global and Regional Powers: Relations, Problems and Issues in the $21^{\text {st }}$ Century. Berlin: Peter Lang. DOI: https://doi.org/10.3726/b16239

Umbach, F. (2007). The legs of the triangle - the EU-China relations. In W. Jung (Ed.), The new strategic triangle: China, Europe and the United States in a changing international system (pp. 36-45). Beijing: Konrad-Adenauer Stiftung, Retrieved from https://nbn-resolving.org/urn:nbn:de:0168-ssoar-131436

Vinocur, N., \& Cerulus, L. (2019, 8 Apr). China's envoy to Europe: Plot your own path, not Washington's. Politico. Retrieved from https://www.politico.eu/article/Chinasenvoy-to-europe-washington-is-getting-between-us/ 
Vogt R. (Ed.). (2012). Europe and China: Strategic Partners or Rivals? Hong Kong: Hong Kong University Press.

Walkowski, M. (2017). Chiński model rozwoju społeczno-gospodarczego i jego potencjalna adaptacja w Europie. Przeglad Strategiczny, 10, 335-365.

Weiss, J. C. (2019). A World Safe for Autocracy? China's Rise and the Future of Global Politics. Foreign Affairs, 98(4).

Wilhelm, B. (2019, 13 Mar). The EU Recalibrates Its Policy on China, a 'Systemic Rival'. World Politics Review. Retrieved from https://www.worldpoliticsreview.com/trendlines/27643/the-eu-recalibrates-its-policy-on-China-a-systemic-rival

Xiang, B. (2017, 17 Mar). Backgrounder: Xi Jinping Thought on Socialism with Chinese Characteristics for a New Era. Xinhua. Retrieved from http://www.xinhuanet.com/ english/2018-03/17/c_137046261.htm

Zhou, H. (Ed.). (2017). China-EU Relations. Reassessing the China-EU Comprehensive Strategic Partnership. Singapore: Springer.

Zhou, H. (2017a). An Overview of the China-EU Strategic Partnership (2003-2013). In Zhou, H. (Ed.), China-EU Relations. Reassessing the China-EU Comprehensive Strategic Partnership (pp. 3-31). Singapore: Springer. 